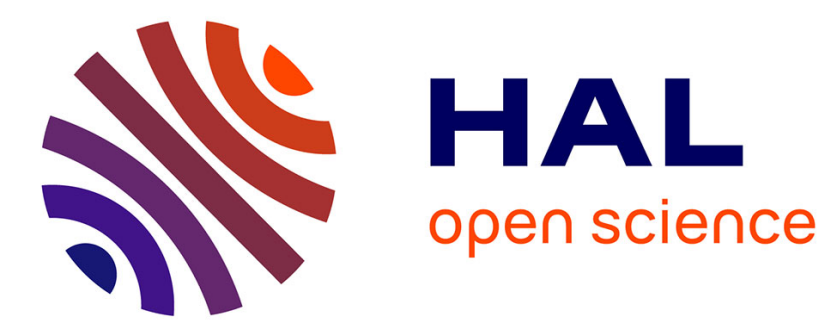

\title{
Taxonomic revision of the Sylvarum group of bumblebees using an integrative approach
}

Nicolas Brasero, Baptiste Martinet, Denis Michez, Thomas Lecocq, Irena Valterova, Pierre Rasmont

\section{- To cite this version:}

Nicolas Brasero, Baptiste Martinet, Denis Michez, Thomas Lecocq, Irena Valterova, et al.. Taxonomic revision of the Sylvarum group of bumblebees using an integrative approach. Systematics and Biodiversity, 2020, 18 (1), pp.12-28. 10.1080/14772000.2020.1737843 . hal-02906102

\section{HAL Id: hal-02906102 \\ https://hal.univ-lorraine.fr/hal-02906102}

Submitted on 11 Dec 2020

HAL is a multi-disciplinary open access archive for the deposit and dissemination of scientific research documents, whether they are published or not. The documents may come from teaching and research institutions in France or abroad, or from public or private research centers.
L'archive ouverte pluridisciplinaire HAL, est destinée au dépôt et à la diffusion de documents scientifiques de niveau recherche, publiés ou non, émanant des établissements d'enseignement et de recherche français ou étrangers, des laboratoires publics ou privés. 
1 Taxonomic revision of the Sylvarum group of bumblebees using an 2 integrative approach

3 Nicolas Brasero ${ }^{1 *}$, Baptiste Martinet $^{1}$, Denis Michez ${ }^{1}$, Thomas Lecocq ${ }^{1.2}$, Irena Valterova ${ }^{3,4}$ and Pierre Rasmont ${ }^{1}$

5 1: University of Mons, Research institute of Biosciences, Laboratory of Zoology, Place du 6 Parc 20, 7000 Mons, Belgium (brasero.nicolas@gmail.com)

7 2: University of Lorraine, INRA, URAFPA, F-54000 Nancy, France

8 3: Academy of Sciences of the Czech Republic, Institute of Organic Chemistry and 9 Biochemistry, Flemingovo nám 2, CZ-166 10 Prague, Czech Republic 4: Czech University of Life Sciences, Faculty of Tropical AgriSciences, Kamýcká 129, CZ16521 Prague, Czech Republic

* corresponding authors

\section{$\underline{\text { Acknowledgement }}$}

This work was supported by the Institute of Organic Chemistry and Biochemistry of the Academy of Sciences of the Czech Republic under grant number 61388963; the FRS-FNRS (Fonds de la Recherche Scientifique) under grant number 2013/V 3/5/307-IB/JN-11888 and the European Community's Seventh Framework Program, STEP Project (Status and Trends of European Pollinators, www.step-project .net, under grant number 244090, FP7/2007-2013). 


\section{Abstract}

Recent improvements in taxonomy consider multiple operational criteria. Integrative taxonomy provides a methodological framework merging these multisource approaches. Bumblebees are considered as a uniform group where their taxonomy remains one of the most difficult. Here, we investigate the taxonomic statuses inside a monophyletic group including six taxa (B. inexspectatus, B. mlokosievitzii, B. ruderarius, B. sylvarum, B. velox and B. veteranus) in the most diverse subgenus of bumblebees: Thoracobombus. We used an integrative approach based on mitochondrial and nuclear genetic markers and eco-chemical traits commonly used in bumblebee taxonomy. For all species, our study shows a clear differentiation in DNA and eco-chemical traits. However, we conserve the subspecies status of $B$. ruderarius simulatilis and B. sylvarum daghestanicus from the east of Turkey and Iran according to their degree of genetic and eco-chemical differentiation.

Keywords: Bumblebees, eco-chemical traits, integrative taxonomy, mitochondrial genetic maker, nuclear genetic maker, Thoracobombus.

\section{Introduction}

Species are considered as the fundamental unit in biology and their accurate delimitation is essential respectively in biodiversity classification and in evolutionary and conservation biology (Moraes, 1987; Paquin, Dupérré, Cokendolpher, White \& Hedin, 2008; Wheeler, Raven \& Wilson, 2004). Taxonomy inside invertebrate groups is mainly based on morphological approach. However, the common strong homogeneity in morphology may be an obstacle for identification, especially in the case of cryptic species (Williams et al., 2012). Moreover, many species exhibit a high intra-specific variability and cases of convergent color pattern were recorded in sympatry (Françoso, Freitas de Oliveira \& Arias, 2016; Lecocq et al., 2015a). Therefore, many alternative features and methods such as DNA-based approaches 
(e.g. pairwise distance thresholds, bootstrap support or reciprocal monophyly), geometric morphometrics of wing shape or semiochemical traits have been used to delineate species (Lecocq et al., 2015b; Martin, Helantera \& Drijfhout, 2008; Oleksa \& Tofilski, 2015; White, Pilgrim, Boykin, Stein \& Mazor, 2014). In order to draw a strongly supported taxonomic hypothesis, recent betterment in taxonomy consider multiple operational criteria from the same sampling (Gibbs, 2009; Lecocq et al., 2011; Martinet et al., 2018). The integrative taxonomy based on the Unified Species Concept (USC) provides a methodological framework merging these multisource approaches (De Queiroz, 2007; Padial, Miralles, De la Riva \& Vences, 2010; Schlick-Steiner et al., 2010). The USC argues that all species concepts agree that species exist as separately evolving metapopulation lineages but diverge in their criterion for delimiting species (De Queiroz, 2007). Therefore, ecological differentiation, phylogenetic divergence, morphological characteristic or reproductive isolation could highlight a metapopulation lineage separation by avoiding false taxonomic conclusions driven by a single trait. Moreover, by considering subspecies as a step in the process of allopatric speciation (Mayr, 1942), and because of its important value in conservation and evolutionary biology (Coppée, Terzo, Valterová \& Rasmont, 2008; Phillimore \& Owens, 2006; Rasmont, Coppée, Michez \& De Meulemeester, 2008; Sackett et al., 2014; Terzo, Urbanová, Valterová \& Rasmont, 2005), subspecies status has been proposed as solution when differentiation is highlighted by a subset of operational criteria. This proposal aims to reduce the underestimate risk of a congruence approach (Hawlitschek, Nagy \& Glaw, 2012; Padial et al., 2010).

Bumblebees are considered as a complex group where their classification remains one of the most difficult in bees (Moure \& Sakagami, 1962; Murray, Fitzpatrick, Brown \& Paxton, 2008). In this group, integrative taxonomy has considerably improved taxonomic studies and has solved many doubtful cases thanks to operational criteria as DNA (mitochondrial and 
nuclear) and semio-chemicals (Bertsch, Schweer, Titze \& Tanaka, 2005; Lecocq et al., 2015a; Martinet et al. 2018 ).

In this paper, we apply an integrative approach to assess the taxonomic status of a group of phylogenetically closely related species in the Thoracobombus Dalla Torre, 1880 subgenus: B. mlokosievitzii Radoszkowski, 1877, B. ruderarius (Müller, 1776), B. sylvarum (L., 1761), B. velox (Skorikov, 1914), B. veteranus (Fabricius, 1793) and Bombus inexspectatus (Tkalců, 1963). We revise the taxonomy of this group through a decision framework based on differentiation of three operational and independent criteria commonly used in bumblebee taxonomy: a mtDNA marker (COI), a nuDNA marker (PEPCK) and an eco-chemical trait.

\section{$\underline{\text { Materials and methods }}$}

\section{Studied taxa}

B. ruderarius (Müller, 1776) is a widespread species distributed from Tunisia in the south to the Arctic Circle in the north (Rasmont et al., 2015a). Four subspecies and one form have been described (Rasmont, 1983): (i) B. ruderarius ruderarius (Müller, 1776) is characterized by a reddish tail and the rest of the body is black intermixed with more or less greyish hairs (Fig. 1C). They occurred throughout Europe except the Mediterranean region; (ii) $B$. ruderarius simulatilis Radoszkowski, 1888 with a wide white collare and scutellare bordering a black interalar band, the tergite 1 and 2 completely white and with the tergite 3 black, the tail is red (Fig. 1D). This subspecies occurred in mountainous regions of Anatolia as well as in the Caucasus region in north Iran; (iii) B. ruderarius tunensis (Tkalců, 1974) is characterized by three yellow bands and a white tail and is endemic to the east of Algeria and north of Tunisia; (iv) B. ruderarius sartus (Skorikov, 1922) with a wide yellowish collare and scutellare bordering a black interalar band, the tergite 1 and 2 completely yellowish and with the tergite 3 black, the tail is red. The eastern limits of the species were known to be the 
mountains of east Turkestan but other specimens were found in Mongolia (Skorikov, 1922); (v) B. ruderarius form montanus is characterized by large yellowish bands compared to the dark nominal subspecies (Fig. 1C). They occur from the Cantabrian Mountains to the Pyrenees where they coexist with the nominal subspecies $B$. ruderarius ruderarius.

B. sylvarum (L., 1761) is also a widespread species distributed in the west-palaearctic region but hardly reaches Mongolia (Rasmont et al., 2015a). We considered four subspecies and one form (Rasmont, 1983): (i) B. sylvarum sylvarum (L., 1761) with three large greyish bands (thorax and abdomen) and thin grey bands (abdomen) and a reddish tail intermixed with grey (Fig. 1F). They occur in the west-Palaearctic region; (ii) B. sylvarum citrinofasciatus Vogt, 1909 is characterized by grey yellowish bands compared to the nominal subspecies. Moreover, the thin grey bands on the abdomen are often absent. They occur in the west of Turkey; (iii) B. sylvarum daghestanicus Radoszkowski, 1877 is characterized by white bands and a reddish tail (Fig. 1E). This subspecies is distributed in the east of Turkey, the Caucasus region as well as in Iran; (iv) B. sylvarum rogenhoferi Dalla Torre, 1882 with white yellowish bands, a red tail and without thin grey bands on the abdomen is restricted to south Italy and Sicily; (v) B. sylvarum form nigrescens Pérez, 1879 is considered as the melanic form inside B. sylvarum species. They are completely black with a reddish tail and with or without intermixed grey hairs on the thorax (Fig. 1G). They occur in the south-west of France, the Atlantic regions as well as the south of Scandinavia. Currently, all these subspecies and form are considered as B. sylvarum (Rasmont et al., 2015a; Williams, 1998).

All other species included in this paper form a monophyletic group with $B$. ruderarius and $B$. sylvarum (Cameron, Hines \& Williams, 2007) and will be treated as comparison group.

Bombus inexspectatus (Tkalců, 1963) (Fig. 1A) is a sub-alpine uncommon European species restricted in the Cantabrian Mountains and the Alps from 1200m to 2100m in altitude (Amiet, 1996; Rasmont et al., 2015a; Tkalců, 1963, 1965; Yarrow, 1970). It has been described as a 
species adapted to parasitic life (Müller, 2006; Yarrow, 1970) with B. ruderarius as its only host (Müller, 2006). There is no doubt about its specific status.

B. mlokosievitzii Radoszkowski,1877 is a ponto-mediterranean species whose distribution extends from the Balkan Mountains to Caucasian region via the south of the Black Sea (Rasmont \& Iserbyt, 2014). Three subspecies diagnosable by their coat color variation has been defined: (i) B. mlokosievitzii mlokosievitzii Radoszkowski, 1877 with a wide greyish white collare and scutellare bordering a black interalar band. This subspecies is distributed in the north of Anatolia; (ii) B. mlokosievitzii convergens Skorikov, 1908 characterized by a thorax completely greyish white is distributed in the Caucasian region and (iii) $B$. mlokosievitzii vogtiellus diagnosable by their thorax completely black (Fig. 1B) and distributed in Greece, Macedonia, Bulgaria and west of Anatolia. The presence of a reddish band on tergite 2 is common to all subspecies. Unfortunately we were not able to collect all subspecies inside this taxon and only the subspecies mlokosievitzii was considered in this study.

B. velox (Skorikov, 1914) is restricted to the north east of Anatolia and the Caucasus region. It is an uncommon species with two greyish bands on the thorax and one on the tergite 1, the rest of the abdomen is yellowish (Fig. 1H). There is no doubt about its specific status.

B. veteranus (Fabricius, 1793) lives in sparse population in the plains of northern Europe (Rasmont \& Iserbyt, 2014). This species presents very little color variation and is characterize by a yellowish coat color on all the body except the presence of a black interalar band (Fig. 1I). There is no doubt about its specific status.

\section{Sampling}

150 male and female specimens were collected between 2001 and 2017 in the Palaearctic region (supplementary file 1, Tab. 1). All specimens were determined based on their morphology. We attributed a name to the specimens without taxonomic a priori on the species 
status. The ingroup comprises: ruderarius from Estonia $(n=5)$, France $(n=16)$, Macedonia $(n=1)$, Serbia $(n=1)$, Slovakia $(n=4)$, Sweden $(n=1)$ and Switzerland $(n=5)$, montanus from Andorra (n=3), Spain (n=2) and France $(n=5)$, simulatilis from Iran $(n=3)$ and Turkey $(n=9)$, sartus from Kyrgyzstan ( $\mathrm{n}=2)$ and Mongolia $(\mathrm{n}=2)$, sylvarum from Belgium $(\mathrm{n}=3)$, France $(=13)$, Germany $(n=4)$, Italy $(n=3)$, Poland $(n=6)$, Serbia $(n=2)$, Slovakia $(n=1)$, Spain $(n=2)$ and Sweden $(\mathrm{n}=4)$, daghestanicus from Iran $(\mathrm{n}=1)$ and Turkey $(\mathrm{n}=8)$, nigrescens from Spain $(n=1)$ and Sweden $(n=5)$, rogenhoferi from Italy $(n=2)$. The comparison group comprises: inexspectatus from Italy $(\mathrm{n}=9)$; mlokosievitzii from Turkey $(\mathrm{n}=11)$, velox from Turkey $(\mathrm{n}=1)$ and veteranus from Belgium $(n=4)$, France $(n=4)$ and the Netherlands $(n=4)$. The phylogenetically related species $B$. mucidus (n=3) was used as outgroup.

Genetic trait analyses

Two genes commonly used in bumblebee phylogeny were sequenced (Cameron et al., 2007; Martinet et al., 2018; Williams et al., 2012): the "barcode" region of the cytochrome oxidase 1 (COI) mitochondrial gene was sequenced from 88 specimens, and the nuclear protein-coding gene phosphoenolpyruvate carboxykinase (PEPCK) was sequenced from 83 specimens (supplementary file 1).

We carried out polymerase chain reaction amplifications with new design primer pairs CSylG-F/CSylG-R: (5'-TGATCAGGAATAATTGGATCTTCA-3') TGATCAGGAATAATTGGATCTTCA-3') for COI and PSylG-F/PSylG-R: (5'CTTTAAAGGCAATTGTATCAAAGTT-3') / (5'-CTCGCCAATCGGTGATCTAT-3') for PEPCK. We performed sequencing procedures described in Lecocq et al. (2013). Sequences were aligned with BioEdit version 7.2.5 (Hall, 1999). The resulting COI (624bp) and PEPCK (894bp) sequences are available on GenBank (accession numbers in supplementary file 1).

We investigated the potential genetic differentiation for each gene individually within the six taxa through haplotype networks analyses. We used the median-joining method with Network 
4.6.1.1 software (www.fluxus-engineering.com) to produce haplotype networks. We weighted transversions twice as high as transitions to reconstruct the network (Lecocq et al., 2015a; Martinet et al., 2018). In phylogenetic analyses, gaps (deletion or insertion) are usually treated as missing data. Because of the presence of gaps sites in our PEPCK genes, two haplotype networks considering or not the gaps sites will be performed in order to be aware of phylogenetic information provide by these two methods.

In phylogenetic analyses, we analyzed each gene independently with maximum likelihood (ML) and Bayesian (MB) methods to explore the genetic divergence and define lineages within the different groups. For ML methods, we partitioned each gene to explore the best substitution model: i) PEPCK into two introns and one exon; ii) COI and PEPCK exons by base position $\left(1^{\text {st }}, 2^{\text {nd }}\right.$ and $\left.3^{\text {rd }}\right)$ and choose the best fitting substitution models with JModelTest Server 2.0 (Posada, 2008) using the Akaike information criterion corrected for small sample sizes (Hurvich \& Tsai, 1989). The chosen models were: i) For COI: TIM1 + I (1 $\left.{ }^{\text {st }}\right)$, HKY $\left(2^{\text {nd }}\right)$, and TPM3uf $+\mathrm{I}\left(3^{\text {rd }}\right)$; ii) for PEPCK, exon: F81 $\left(1^{\text {st }}\right), \mathrm{JC}\left(2^{\text {nd }}\right), \mathrm{K} 80\left(3^{\text {rd }}\right)$; intron 1 : TMP3uf + I; intron 2: HKY. Selected models which are not implemented in MrBayes were substituted by the closest over-parameterized model. For each gene, ML analyses were performed with ten independent runs in Garli 2.0 (Zwickl, 2006); the topology and -ln L was the same among replicates. The run with the highest likelihood was retained. Statistical significance in nodes was evaluated with 10000 non-parametric bootstrap replicates. Topologies with bootstrap values $\geq 85 \%$ were considered as well supported (Hillis \& Bull, 1993). For MB method, we performed Bayesian inference analyses with mrbayes 3.1.2 (Ronquist \& Huelsenbeck, 2003). Ten independent analyses were achieved for each gene (100 million generations, four chains with mixed models, default priors, saving trees every 1000 generations). Then the first 10 million generations were removed as burn-in procedure. A majority-rule $50 \%$ consensus tree was constructed. We considered as statistically significant 
only branch supports (topologies) with high posterior probabilities $(\geq 0.95)$ (Wilcox, Zwickl, Heath \& Hillis, 2002). The phylogenetic analysis based on PEPCK gene fragment considered gaps as missing data. All trees were rooted with the taxon B. mucidus.

In order to recognize species threshold, we applied the Bayesian implementation of the general mixed Yule-coalescent (bGMYC) method to the COI dataset by using R Package "bGMYC" (Reid \& Carstens, 2012). A range of probabilities < 0.05 was considered as strong evidence that taxa was heterospecific while a range of probabilities $>0.95$ suggested that taxa was conspecific (Reid \& Carstens 2012). BEAST 1.7.4 (Drummond, Suchard, Xie \& Ranbaut, 2012) was used to generate ultrametric trees with a phylogenetic clock model in order to calculate a posterior distribution of trees (length of the MCMC chain: 1 billion generations). The first million sampled trees were burned-in using the maximum clade credibility method and setting the posterior probability limit to 0. The bGMYC analysis was based on 1000 trees sampled every 10000 generations. For each of these 1000 trees, the MCMC was made of 100000 generations, discarding the first 90000 as burn-in and sampling every 100 generations.

\section{Eco-chemical trait analyses}

We focused on the cephalic labial gland secretions (CLGS) of males, the most commonly reproductive trait involved in the bumblebee pre-mating recognition (Ayasse \& Jarau, 2014). Currently, the composition of the CLGS is known for 15 species of Thoracobombus (Ayasse \& Jarau, 2014; Brasero et al., 2015; Brasero et al., 2018a,b) and this study will increase the knowledge inside this group to 17 species. These secretions are species-specific (Calam, 1969) and provide an efficient diagnostic characters for species delimitation (Brasero et al., 2015). They are complex mixtures of mainly aliphatic compounds synthesized de novo (Coppée et al., 2008; Žáček et al., 2013) in the head of bumblebee males. Main components were defined as those with the highest relative amount in at least one individual of the taxon. 
All specimens were killed by freezing at $-20^{\circ} \mathrm{C}$ and the CLGS were extracted with $400 \mu \mathrm{l}$ of heptane (method described in De Meulemeester, Gerbaux, Boulvin, Coppée, \& Rasmont, 2011). Samples were stored at $-40^{\circ} \mathrm{C}$ prior to analysis. We were able the sample 111 specimens belonging to the six studied taxa (Tab. 1).

We determined the CLGS composition by gas chromatography-mass spectrometry (GC/MS) using a Focus GC (Thermo Scientific) with a non-polar DB-5 ms capillary column [5\% phenyl (methyl) polysiloxane stationary phase; column length $30 \mathrm{~m}$; inner diameter $0.25 \mathrm{~mm}$; film thickness $0.25 \mu \mathrm{m}$ ] coupled to DSQ II quadrupole mass analyzer (Thermo Scientific) with $70 \mathrm{eV}$ electron impact ionization. We used a splitless injection mode $\left(220^{\circ} \mathrm{C}\right)$ and helium as a carrier gas (one $\mathrm{ml} / \mathrm{min}$ ). The temperature program of the oven was set to $70^{\circ} \mathrm{C}$ for two minutes and then heated up at a rate of $10^{\circ} \mathrm{C} / \mathrm{min}$ to $320^{\circ} \mathrm{C}$. The temperature was then held at $320^{\circ} \mathrm{C}$ for five minutes. Compounds were identified in $\mathrm{Xcalibur}^{\mathrm{TM}}$ using the retention times $\left(\mathrm{t}_{\mathrm{r}}\right)$ and mass spectra of each peak, in comparison to those at National Institute of Standards and Technology library (NIST, U.S.A). Double bond positions $(\mathrm{C}=\mathrm{C})$ were determined by dimethyl disulfide (DMDS) derivatization (Cvacka et al., 2008).

The CLGS compounds of all samples were quantified by a gas chromatograph-flame ionization detector Shimadzu GC-2010 with a SLB-5ms non-polar capillary column (5\% phenyl (methyl) polysiloxane stationary phase; 30-m column length; 0.25 -mm inner diameter; $0.25-\mu \mathrm{m}$ film thickness) with the same chromatographic conditions as in GC/MS. Peak areas of compounds were detected in GCsolution Postrun (Shimadzu Corporation) with automatic peak detection and noise measurement. We calculated relative amounts (RA in \%) of compounds in each sample by dividing the peak areas of compounds by the total area of compounds. We discarded all compounds for which RA were recorded as less than $0.1 \%$ for all specimens (De Meulemeester et al., 2011). The data matrix (supplementary file 2) for each 
taxon was based on the alignment of each relative proportion of compound between all samples performed with GCAligner 1.0 (Dellicour \& Lecocq, 2013).

Before each samples injection, a standard (Kovats) containing a mix of hydrocarbons (alkanes) from $\mathrm{C} 10$ (decane) to $\mathrm{C} 40$ (tetracontane) was injected in order to facilitate the alignment and the identification of compounds. Kovats indices were calculated with GC Kovats 1.0 (Dellicour \& Lecocq, 2013).

Clustering method were performed using R 3.3.2 (R Development Core Team, 2016) to detected CLGS differentiations between taxa. A Canberra distance matrix based on CLGS (RA of each compound) was computed. An unweighted pair group method with arithmetic mean (UPGMA) was used as clustering method (R-package ape, Suzuki \& Shimodaira, 2011). We assessed the uncertainty in hierarchical cluster analysis using $p$-values calculated via multiscale bootstrap resampling with 50000 bootstrap replications (significant branch support > 0.85) (R-package pvclust, Suzuki \& Shimodaira, 2011). We assessed CLGS differentiations between taxa by performing a permutation multivariate analysis of variance using distance matrix (perMANOVA) (R package vegan; Oksanen et al., 2011). When a significant difference was detected, we performed a pairwise multiple comparison with an adjustment of $P$-values (Bonferroni correction) to avoid type I errors.

To determine the indicator compounds (IC) of each taxon, we used the indicator value (IndVal) method (Claudet, Pelletier, Jouvenel, Bachet \& Galzin, 2006; Dufrêne \& Legendre, 1997). The value given is the product of relative abundance and relative frequency of occurrence of a compound within a group. We evaluated the statistical significance of a compound as an indicator at the 0.01 level with a randomization procedure.

\section{Decision framework of taxonomic status}

We used an approach that corresponds to the strictest commonly used framework called "integration by congruence" by Padial et al. (2010). We thus assigned the specific status to a 
taxon (i) genetically differentiated in all genetic markers (i.e. unique haplotypes), (ii) which constitute a monophyletic group with high branch support, and (iii) with a significant differentiation in CLGS composition (significance differentiation in perMANOVA and high bootstrap values $>0.85$ ). All criteria used must be convergent to assign specific status. This approach can lead to underestimation of species differentiation but reduces the taxonomic inflation. We assigned the subspecies status to phenotypically distinct allopatric population that does not diverge in all lines of evidence. This decision reduces the 'underestimate's risk' of our strict integrative approach by naming them as a subspecies (Ennen et al., 2014; Hawlitschek et al., 2012).

\section{$\underline{\text { Results }}$}

\section{Genetic trait analyses}

All phylogenetic analyses (ML and MB) showed the expected differentiation between outgroup and ingroup (Fig. 2A, 3A). Seven strongly supported (bootstrap>0.95) monophyletic groups are detected in our COI phylogenetic analyses (Fig. 2A): (i) one group with inexspectatus specimens; (ii) one group with ruderarius, montanus, sartus and simulatilis specimens; (iii) one with velox specimens; (iv) one group with veteranus specimens; (v) one group including all sylvarum, nigrescens, daghestanicus and rogenhoferi specimens; (vi) one group with mlokosievitzii specimens and (vii) the outgroup B. mucidus. Within "ruderarius group", two unexpected lineages were revealed (Fig. 2A): one main lineage strongly supported including the widespread ruderarius taxa, montanus and sartus and one another lineage not strongly supported (bootstrap<0.95) including simulatilis taxon from Turkey and Iran. As expected, we found a less structured tree in the PEPCK gene fragment for all taxa. PEPCK gene analyses showed little phylogenetic information and failed to reconstruct the phylogenetic affinities between all taxa (Fig. 3A). However, we found some strongly 
supported groups as inexspectatus and mlokosievitzii. As for COI gene, no geographical entities were underlined by our PEPCK phylogenetic analyses expected for "ruderarius group" where the unexpected lineage simulatilis was revealed and strongly supported in our MB (Fig. 3A) but not in our ML analysis.

15 private haplotypes were highlighted for COI gene while 11 and 10 haplotypes were highlighted in PEPCK genes respectively considering or not the gaps sites by our network analysis (Fig. 2B, 3B, C). Within the "ruderarius and sylvarum groups", only simulatilis displayed specific haplotypes in COI and PEPCK, while daghestanicus had specific COI haplotype (Fig. 2B, 3B, C). Considering all taxa, COI revealed 72/624 nucleotide sites substitution corresponding to $11.54 \%$ of phylogenetic information. Compared to the taxa inside their groups, simulatilis and daghestanicus revealed respectively $0.96 \%$ (6/624 diagnostic nucleotide sites) and $0.64 \%$ (4/624 diagnostic nucleotide sites) of phylogenetic information in COI gene (Fig. 2B). Considering all taxa, PEPCK gene revealed 143/894 (considering gaps) and 23/894 (not considering gaps) nucleotide sites respectively corresponding to $16 \%$ and $2.6 \%$ of phylogenetic information. Compared to the taxa inside their groups, simulatilis revealed $1.79 \%$ (16/894 diagnostic nucleotide sites) of phylogenetic information when gaps are considered (Fig. 3C) and 0.34\% (3/894 diagnostic nucleotide sites) when gaps are not considered (Fig. 3B).

The tree generated by bGMYC analysis highlighted several entities with low probabilities $(<0.05)$ to be conspecific with the other ones (Fig. 4). It suggested the delimitation of 7 prospective species $(\mathrm{P}<0.05)$ (Fig. 4) which match with those obtained in the COI tree (ML and $\mathrm{MB}$, Fig. 2A): (i); one group with inexspectatus specimens $(\mathrm{P}=1)$; (ii); one group with velox specimens $(\mathrm{P}=1)$; (iii) one group with ruderarius, sartus, montanus and simulatilis specimens ( $\mathrm{P}>0.16-1)$; (iv) one group with veteranus specimens $(\mathrm{P}=1)$; (v) one group including sylvarum, daghestanicus, nigrescens, rogenhoferi specimens ( $\mathrm{P}>0.34-1)$; (vi) one 
group with mlokosievitzii specimens $(\mathrm{P}=1)$ and (vii) one group with the outgroup $B$. mucidus $(\mathrm{P}=1)$. The pairwise matrix shows a non significant heterospecificity threshold between simulatilis and the other taxa from ruderarius group $(\mathrm{P}>0.05)$.

\section{Eco-chemical trait analyses}

The chemical analyses highlighted 7 strongly supported groups (bootstrap > 85\%) (Fig. 5). A: velox (Turkey); B: inexspectatus (Italy); C: mlokosievitzii (Turkey), D: sylvarum + daghestanicus + nigrescens + rogenhoferi (Belgium, France, Germany, Iran, Italy, Poland, Serbia, Slovakia, Spain, Sweden and Turkey); E: veteranus (Belgium, France and Holland); F: montanus + ruderarius (Andorra, Estonia, France, Macedonia, Serbia, Slovakia, Spain, Sweden and Switzerland) and G: simulatilis (Turkey). 95 compounds were detected (respectively 17 from $\mathbf{A}, 36$ from $\mathbf{B}, 34$ from $\mathbf{C}, 55$ from $\mathbf{D}, 36$ from $\mathbf{E}, 49$ from $\mathbf{F}$ and 44 from G; see supplementary file 2). For each group, we detected main compounds, A: octadecen-1-ol (88.2\%); B: hexadec-7-en-1-ol (17.2-57.8\%), octadec-11-en-1-ol (12.2-32.6\%) and octadec-11-enyl acetate (10-23.4\%); C: hexadec-7-en-1-ol (14-46.7\%) and hexadec-7enyl acetate (19.6-45.9\%); D: hexadec-7-en-1-ol (2.2-57.5\%) and hexadec-7-enyl acetate (20.1-66.6\%); E: hexadec-9-en-1-ol (1.1-57.8\%) and ethyl octadec-11-enoate (1.5-31.4\%); F: hexadec-9-en-1-ol (0-62.3\%), hexadec-9-enyl acetate $(0-32.7 \%)$, tricos-9-ene + tricos-7-ene (2.1-59.2\%) and hexadecenyl hexadecenoate2 (0.1-25.1\%) and G: hexadec-9-en-1-ol (4.5$59.9 \%)$, octadecadien-1-ol (0.4-22\%), and tricos-9-ene + tricos-7-ene $(5.7-54.2 \%)$ and tricosane (2-20\%). Moreover, the IndVal method highlighted several significantly indicator compounds (IC) (IndVal value>70) for the group A (IC=4), B (IC=11), C (IC=3), D (IC=7), $\mathbf{E}(\mathrm{IC}=5), \mathbf{F}(\mathrm{IC}=1)$ and $\mathbf{G}(\mathrm{IC}=0)$ (supplementary file 2). Despite the separation we observed between montanus + ruderarius and simulatilis our IndVal method did not find indicator compounds for simulatilis, however, our statistical analysis significantly supports this differentiation (bootstrap $>85 \%$ ). perMANOVA test confirmed the differentiations between 
all groups (see supplementary file 3) and particularly between montanus + ruderarius and simulatilis (p-value: 0.041; F: 2.9986).

\section{Decision framework of taxonomic status}

Within the "ruderarius group" (ruderarius, sartus, montanus and simulatilis), operational criteria did not reflect the current subspecific differentiation (Tab. 2). CLGS and haplotype networks analyses detected differentiation between simulatilis and the other taxa. We then considered B. ruderarius simulatilis as a subspecies inside the "ruderarius group". This subspecies occurs in mountainous regions of Anatolia, the Caucasus region as well in north Iran. We also assigned the subspecific status B. ruderarius ruderarius (Müller, 1776) to the other taxa (Tab. 2).

The genetic structure observed in COI, PEPCK and CLGS did not reflect the current subspecific status encountered in the "sylvarum group" (sylvarum, daghestanicus, nigrescens and rogenhoferi). Based on its unique haplotype in COI we decided to consider B. sylvarum daghestanicus as a subspecies inside the "sylvarum group" as described by Radoszkowski (1877). This subspecies occurred in mountainous regions of Anatolia, the Caucasus region as well in Iran. We then assigned the subspecific status B. sylvarum sylvarum (Müller, 1776) to the other taxa inside which we considered the forms sylvarum, nigrescens and rogenhoferi based on their color patterns (Tab. 2). The specific status of B. inexspectatus, $B$. mlokosievitzii, B. velox and B. veteranus were confirmed by our results.

\section{$\underline{\text { Discussion }}$}

Genetic character along with CLGS can confirm with a high degree of certainty the speciation processes between taxa. We established the species status of our different taxa according to their divergences in genetic markers (mitochondrial and nuclear) and their CLGS differentiation (Tab. 2). 
Our integrative approach support the specific status of all closely related consubgeneric six species studied here (Cameron et al., 2007; Williams, 1998). Similar interspecific differentiations were recorded independently based on DNA (Cameron et al., 2007, Hines \& Cameron, 2010) and CLGS composition (Appelgren, Bergstrom, Svensson \& Cederberg, 1991; Brasero et al., 2018a; Terzo et al., 2005). However, the analyses in this study were carried out on a larger sampling covering the distribution of the species. Within "ruderarius group" and "sylvarum group" and despite some phenotypic differentiations, all studied taxa are regarded as conspecific (Tab. 2). ruderarius and sylvarum groups appear respectively as single species with high geographic phenotypic differentiations. In the light of our results, we decide for the "sylvarum group" to use the oldest available nominal species name as the valid name for all of them: B. sylvarum sylvarum except for daghestanicus where we maintain the subspecific status B. sylvarum daghestanicus from east of Turkey and Iran because of its private haplotype in COI. Inside the "ruderarius group" we decide to conserve the subspecific status $B$. ruderarius simulatilis for the population in the east of Turkey and Iran based on their CLGS differentiation and private haplotype (COI and PEPCK) and raised the other populations to the oldest available nominal species name $B$. ruderarius ruderarius (see decision framework Tab. 2). For the comparison groups B. inexspectatus, B. mlokosievitzii, B. veteranus and B. velox, our analyses (Fig 2A, 3A, 4 \& 5) confirm clear differentiation between these species (Cameron et al., 2007; Hines \& Cameron, 2010). Inside $B$. mlokosievitzii, we have not been able to analyze the subspecies convergens and vogtiellus.

\section{Intraspecific differentiation of $\mathrm{B}$. sylvarum and $\mathrm{B}$. ruderarius}

B. sylvarum is a widespread species and can be found in Central Spain, Sicily, southern Italy, Greece and Southern Turkey of its distribution. It reaches Ireland and northem Portugal to the West and Mongolia to the East. To the north, this species nearly reaches the Arctic Circle (Rasmont et al., 2015a). Divergence of color patterns (sometimes very pronounced: see the 
melanic form nigrescens), seems to be a simple intraspecific variation as encountered in other bumblebees species such as B. pascuorum (Lecocq, Brasero, Martinet, Valterova \& Rasmont, 2015c). However, even if unique haplotypes (Fig. 2B) are found in daghestanicus (COI gene), there were not strongly supported as reciprocally monophyletic group in our phylogeny (Fig. 2A). No private haplotype was found in PEPCK gene for this taxon (Fig. 3B, C). Moreover, inside the "sylvarum group", high probabilities $(>0.05)$ to be conspecific is showed by the bGMYC analyses (Fig. 4). On the other side, the CLGS did not highlight any divergence between the different populations which would imply that all of them could recognize each other as sexual partners.

$B$. ruderarius is also a widespread species and its distribution is almost identical to that of $B$. sylvarum. However, B. ruderarius is absent from Sicily and the southern Italy but the subspecies B. ruderarius tunensis occurs in the east of Algeria and Tunisia (Rasmont et al., 2015a). The same configuration as in B. sylvarum has been highlighted. Indeed, the divergence in color patterns seems to be a simple intraspecific variation and no diagnostic character was found to discriminate significantly the different population inside $B$. ruderarius. The unique haplotypes found in COI and PEPCK (Fig. 2B, 3B, C) for simulatilis were not strongly supported as reciprocally monophyletic group in our phylogenies (Fig. 2A, 3A) as well in our bGMYC analyses (Fig. 4). However, the CLGS of this Turkish population differ from other populations and it is well supported in our cluster analysis (Fig. 5) but share main compounds (hexadec-9-en-1-ol, tricos-9-ene + tricos-7-ene) with the other $B$. ruderarius taxa (supplementary file 2). We can therefore hypothesize that this divergence involved in the recognition system is not sufficient to induce a pre-mating reproductive barrier. This geographic differentiation sharing main compounds could suggest only a dialect between populations as already described in moths (Tòth et al., 1992) and solitary bees (Vereecken, Mant \& Schiestl, 2007). Although the taxon simulatilis seems more advanced on the path of 
speciation than daghestanicus, complementary tests based on ethological behavior are needed. We then hypothesize that these results could reflect the recent divergence of these taxa. Unfortunately, we have not been able to analyze the subspecies citrinofasciatus and tunensis respectively inside the "sylvarum group" and the "ruderarius group".

Turkey is divided by a diagonal belt which is a massive structure formed by continuous mountains (Miocene-Pliocene) from the north-east towards the south-west. These mountains isolated populations from east and west in many species of insects or plants (Çiplak, Demisroy \& Bozcuk, 1993; Çiplak, 2003; Ekim \& Güner, 1986). Moreover, the distribution of taxa from the West of this barrier generally spread through Europe while the taxa from the east spread through Iran and Asia. In addition with this geographical particularities, climatic change during the ice ages pushed many northern populations especially those found in the Balkans and Caucasus to the south and led to their isolation and speciation at higher altitudes (Hewitt, 1996, 2000). These two taxa (B. ruderarius simulatilis and B. sylvarum daghestanicus) are known to occur in the east part of the diagonal belt and may have colonized Turkey from Caucasus and Asia while the taxa to the west of this barrier may have colonized Turkey from Balkans. It is also interesting to note that B. sylvarum daghestanicus and $B$. ruderarius simulatilis are characterized by the same color pattern (white bands and red tail) (Fig. 1D, E) which could be explained by a local Müllerian mimicry processes (Hines \& Williams, 2012). Other species from other subgenus also posses the same color pattern in this region and could confirm this process: B. cullumanus apollineus (Cullumanobombus), B. sicheli cazuroi and B. incertus (Melanobombus), B. handlirschianus (Mendacibombus), B. brodmannicus (Pyrobombus) and B. niveatus (Sibiricobombus) (Rasmont \& Iserbyt, 2014).

Consider GAPS or not as phylogenetic information?

Our PEPCK gene fragment contains gaps sites (representing an insertion or deletion and also called "indels") and our statistical method for phylogenetic estimation (ML and MB) consider 
the gap as missing data. Indeed, in most of taxonomic studies, the indels are treated as missing data as this is the case for birds (Alström et al., 2015; McKay et al., 2014), frogs (Glaw, Kohler, De la Riva, Vieites \& Vences, 2010), mammals (Ndiaye et al., 2014), spiders (Rezac,

Gasparo, Kral \& Heneberg, 2014). Considered indels will increase the phylogenetic information even if they are located in introns (in our case, all indels are located in the first introns of the PEPCK gene fragment). These gaps reflect the evolutionary history of the taxa and thus contain phylogenetic information which could be very informative particularly for simulatilis where the divergence estimation with all other ruderarius populations remains unclear. It's seems therefore that the treatment of indels has not been fully investigated in taxonomic studies and delimitaion of species. Moreover, in our study, haplotype network analysis considering or not the indels do not bring us any additional information except for $B$. velox which not differs from B. ruderarius if we not considered indels in our analysis (Fig. 3B). Indeed, only gap sites allow to separate B. velox from B. ruderarius. However, both species are respectively strongly differenciated by the genitalia and other morphological characters.

\section{Conservation implication}

Our integrative approach brings to attention the relevance of geographically isolated groups differentiated in genetic and reproductive traits. This strict approach allows defining taxonomic status (species or subspecies) and providing a decision framework for policymakers and conservation organizations. Except for B. inexspectatus (Rasmont et al., 2015b) considered as endangered species in the International Union for Conservation of Nature (IUCN) Red List, B. mlokosievitzii as data deficient (Nieto et al., 2014) and B. velox who is not yet assessed, the other taxa (B. ruderarius, B. sylvarum and B. veteranus) are all considered as least concern by Nieto et al. (2014). Our new taxonomical hypotheses taking into account two subspecies (B. ruderarius simulatilis and B. sylvarum daghestanicus) have 
no implications for the red list assessments. However, the conservation of subspecies with unique haplotypes as well as CLGS differentiation should be seen as source of diversity within respective species and then should be considered and integrated in future management 475 plan.

\section{Acknowledgments}

The authors thank the Parco Nazionale dei Monti Sibillini for granting permission to collect in their respective territories to Paolo Biella. Special thanks go to A. Cetkovic and A. Popovic (University of Belgrade), R. De Jonghe, P. Sagot and V. Cyriaque (University of Mons) for their help in the sampling but also to Simon Dellicour (University of Leuven) for his advices in phylogenetic analyses. Computational resources have been provided by the Consortium des Equipements de Calcul Intensif (CECI), funded by the Belgian FRS-FNRS (Fonds de la Recherche Scientifique). BM contributes as a PhD student granted by the Research Council of University of Mons and by the FRS-FNRS. Part of this work (Eco-chemical trait differentiation) was supported by the Institute of Organic Chemistry and Biochemistry of the Academy of Sciences of the Czech Republic (\#61388963). The research has received funding from the FRS-FNRS (Fonds de la Recherche Scientifique) (2013/V 3/5/307-IB/JN-11888) and the European Community's Seventh Framework Program, STEP Project (Status and Trends of European Pollinators, www.step-project .net, grant agreement no 244090, FP7/2007-2013).

\section{$\underline{\text { References }}$}

Alström, P., Xia, C., Rasmussen, P.C., Olsson, U., Dai, B., Zhao, J., Leader, P.J., Carey, G.J., Dong, L., Cai, T., Holt, P.I., Le Manh, H., Song, G., Liu, Y., Zhang, Y. \& Lei, F. 

(2015). Integrative taxonomy of the Russet Bush Warbler Locustella mandelli complex reveals a new species from central China. Avian Research, 6, 9.

Amiet, F. (1996). Hymenoptera Apidae, 1. Teil: Allgemeiner Teil, Gattungsschlüssel, die Gattungen Apis, Bombus und Psithyrus. Insecta Helvetica Fauna, 12, 1-98.

Appelgren, M., Bergstrom, G., Svensson, B.G. \& Cederberg, B. (1991). Marking pheromones of Megabombus bumble bee males. Acta Chem. Scand, 45, 972-974.

Ayasse, M. \& Jarau, S. (2014). Chemical ecology of bumble bees. Annual review of entomology, 59, 299-319.

Bertsch, A., Schweer, H., Titze, A. \& Tanaka, H. (2005). Male labial gland secretions and mitochondrial DNA markers support species status of Bombus cryptarum and B. magnus (Hymenoptera, Apidae). Insectes Sociaux, 52, 45-54.

Brasero, N., Martinet, B., Urbanová, K., Valterová, I., Torres, A., Hoffmann, W., Rasmont, P. \& Lecocq, T. (2015). First Chemical Analysis and Characterization of the Male SpeciesSpecific Cephalic Labial-Gland Secretions of South American Bumblebees. Chemistry \& Biodiversity, 12, 1535-1546.

Brasero, N., Martinet, B., Lecocq, T., Lhomme, P., Biella, P., Valterova, I., Urbanova, K., Cornalba, M., Hines, H. \& Rasmont, P. (2018a). The cephalic labial gland secretions of two socially parasitic bumblebees Bombus hyperboreus (Alpinobombus) and Bombus inexspectatus (Thoracobombus) question their inquiline strategy. Insect Sciences, 25(1), $75-86$.

Brasero, N., Lecocq, T., Martinet, B., Valterova, I., Urbanova, K., de Jonghe, R. \& Rasmont, P. (2018b). Variability in sexual pheromones questions their role in bumblebee premating recognition system. Journal of Chemical Ecology, 44(1): 9-17.

Calam, D.H. (1969). Species and Sex-specific Compounds from the Heads of Male Bumblebees (Bombus spp.). Nature, 221, 856-857. 
Cameron, S.A., Hines, H.M. \& Williams, P.H. (2007). A comprehensive phylogeny of the bumble bees (Bombus). Biological Journal of the Linnean Society, 91, 161-188.

Çiplak, B. (2003). Distribution of Tettigoniinae (Orthoptera, Tettigoniidae) bush-crickets in Turkey: the importance of the Anatolian Taurus Mountains in biodiversity and implications for conservation. Biodiversity and Conservation, 12, 47-64.

Çiplak, B., Demisroy, A. \& Bozcuk, N. (1993). Distribution of Orthoptera in Relation to the Anatolian Diagonal in Turkey. Articulata, 8, 1-20.

Claudet, J., Pelletier, D., Jouvenel, J.Y., Bachet, F. \& Galzin, R. (2006). Assessing the effects of marine protected area (MPA) on a reef fish assemblage in a northwestern Mediterranean marine reserve: Identifying community-based indicators. Biological Conservation, 130, 349-369.

Coppée, A., Terzo, M., Valterová, I. \& Rasmont, P. (2008). Intraspecific variation of the cephalic labial gland secretions in Bombus terrestris (L.) (Hymenoptera: Apidae). Chemistry \& Biodiversity, 5, 2654-2661.

Cvacka, J., Kofronová, E., Vasícková, S., Stránský, K., Jiros, P., Hovorka, O., Kindl, J. \& Valterová, I. (2008) Unusual fatty acids in the fat body of the early nesting bumblebee, Bombus pratorum. Lipids, 43, 441-450.

Dalla Torre, K.W. (1882). Bemerkungen zur Gattung Bombus Latr. II. Bericht des naturwissenschaftlich-medizinischen Vereins in Innsbruck, 12, 14-31.

Dalla Torre, K.W. (1880). Unsere Hummel-(Bombus) Arten. Die Naturhistoriker, 30, 40-41.

Dellicour, S. \& Lecocq, T. (2013). GCALIGNER 1.0 and GCKOVATS 1.0 - Manual of a software suite to compute a multiple sample comparison data matrix from eco-chemical datasets obtained by gas chromatography. University of Mons, Mons (Belgium).

De Meulemeester, T., Gerbaux, P., Boulvin, M., Coppée, A., \& Rasmont, P. (2011). A simplified protocol for bumble bee species identification by cephalic secretion analysis. 
547 De Queiroz, K. (2007). Species concepts and species delimitation. Systematic Biology, 56, $548 \quad 879-886$.

549 Drummond, A.J., Suchard, M.A., Xie, D. \& Ranbaut, A. (2012). Bayesian phylogenetics with BEAUTI and BEAST 1.7. Molecular biology and evolution, 29(8), 1969-1973.

Dufrêne, M. \& Legendre, P. (1997). Species assemblages and indicator species: The need for a flexible asymmetrical approach. Ecological Monographs, 67, 345-366.

Ekim, T. \& Güner, A. (1986). The Anatolian Diagonal: fact or fiction? Proceedings of the Royal Society of Edinburgh, Section B: Biological Sciences, 89, 69-77.

Ennen, J.R., Kalis, M.E., Patterson, A.L., Kreiser, B.R., Lovich, J.E., Godwin, J. \& Qualls, C.P. (2014). Clinal variation or validation of a subspecies? A case study of the Graptemys nigrinoda complex (Testudines: Emydidae). Biological Journal of the Linnean Society, 111, 810-822.

Fabricius, J.C. (1793). Entomologica systematica emendata at aucta. Secundum classes, ordines, genera, species adjectis synonimis, locis observationibus. Vol. 2. Hafniae.

Françoso, E., Freitas de Oliveira, F. \& Arias, M.C. (2016). An integrative approach identifies a new species of bumblebee (Hymenoptera: Apidae: Bombini) from northeastern Brazil. Apidologie, 47, 171-185.

Gibbs, J. (2009). Integrative taxonomy identifies new (and old) species in the Lasioglossum (Dialictus) tegulare (Robertson) species group (Hymenoptera, Halictidae). Zootaxa, 2032, 1-38.

Glaw, F., Kohler, J., De la Riva, I., Vieites, D.R. \& Vences, M. (2010). Integrative taxonomy of Malagasy treefrogs: combination of molecular genetics, bioacoustics and comparative morphology reveals twelve additional species of Boophis. Zootaxa, 2383, 1-82.

Hall, T.A. (1999). BioEdit: a user-friendly biological sequence alignment editor and analysis 

program for Windows 95/98/NT. Nucleic Acids Symp. Research, 41, 95-98.

Hawlitschek, O., Nagy, Z.T. \& Glaw, F. (2012). Island evolution and systematic revision of comoran snakes: Why and when subspecies still make sense. PLoS ONE, 7(8): e42970.

Hewitt, G.M. (1996). Some genetic consequences of ice ages, and their role in divergence and speciation. Biological Journal of the Linnean Society, 58, 247-276.

Hewitt, G.M. (2000). The genetic legacy of the quaternary ice ages. Nature, 405, 907-913.

Hillis, D.M. \& Bull, J.J. (1993). An empirical test of bootstrapping as a method for assessing confidence in phylogenetic analysis. Systematic Biology, 42, 182-192.

Hines, H.M. \& Williams, P.H. (2012). Mimetic colour pattern evolution in the highly polymorphic Bombus trifasciatus (Hymenoptera: Apidae) species complex and its comimics. Zoological Journal of the Linnean Society, 166, 805-826.

Hines, H.M. \& Cameron, S.A. (2010). The phylogenetic position of the bumble bee inquiline Bombus inexspectatus and implications for the evolution of social parasitism. Insectes sociaux, 57, 379-383.

Hurvich, C.M. \& Tsai, C.L. (1989). Regression and time series model selection in small samples. Biometrika, 76, 297-307.

Lecocq, T., Lhomme, P., Michez, D., Dellicour, S., Valterová, I. \& Rasmont, P. (2011). Molecular and chemical characters to evaluate species status of two cuckoo bumblebees: Bombus barbutellus and Bombus maxillosus (Hymenoptera, Apidae, Bombini). Systematic Entomology, 36, 453-469.

Lecocq, T., Dellicour, S., Michez, D., Lhomme, P., Vanderplanck, M., Valterová, I., Rasplus, J.Y. \& Rasmont, P. (2013). Scent of a break-up: phylogeography and reproductive trait divergences in the red-tailed bumblebee (Bombus lapidarius). BMC evolutionary biology, 13, 263.

Lecocq, T., Brasero, N., De Meulemeester, T., Michez, D., Dellicour, S., Lhomme, P., De 

Jonghe, R., Valterová, I., Urbanová, K. \& Rasmont, P. (2015a). An integrative taxonomic approach to assess the status of Corsican bumblebees: implications for conservation. Animal conservation, 18, 236-248.

Lecocq, T., Dellicour, S., Michez, D., Dehon, M., Dewulf, A., De Meulemeester, T., Brasero, N., Valterová, I., Rasplus, J.Y. \& Rasmont, P. (2015b). Methods for species delimitation in bumblebees (Hymenoptera, Apidae, Bombus): towards an integrative approach. Zoologica Scripta, 44(3), 281-297.

Lecocq, T., Brasero, N., Martinet, B., Valterová, I. \& Rasmont, P. (2015c). Highly polytypic taxon complex: interspecific and intraspecific integrative taxonomic assessment of the widespread pollinator Bombus pascuorum Scopoli 1763 (Hymenoptera: Apidae). Systematic Entomology, 40, 881-890.

Linnaeus, C. (1761). Fauna Suecica sistens animalia Suecica regni: Mammalia, Avec, Amphibia, Pisces, Insecta, Vermes. Distributa per classes \& ordines, genera \& species, cum differentiis specierum, synonymis auctorum, nominibus incolarum, locis natalium, descriptionibus insec.

Martin, S.J., Helantera, H. \& Drijfhout, F.P. (2008). Evolution of species-specific cuticular hydrocarbon patterns in Formica ants. Biological Journal of the Linnean Society, 95, $131-140$.

Martinet, B., Lecocq, T., Brasero, N., Biella, P., Urbanová, K., Valterová, I., Cornalba, M., Gjershaug, J.O., Michez, D. \& Rasmont, P. (2018). Following the cold: geographical differentiation between interglacial refugia and speciation in the arcto-alpine species complex Bombus monticola (hymenoptera: Apidae). Systematic Entomology, 43(1), 200217.

Mayr, E. (1942). Systematics and the Origin of Species. New York.

McKay, B.D., Mays, H.L., Yao, C.T., Wan, D., Higuchi, H. and Nishiumi, I. (2014). 
Oncorporating color into integrative taxonomy: analysis of the varied tit (Sittiparus varius) complex in East Asia. Systematic Entomology, 63(4), 505-517.

Moraes, G.J. (1987). Importance of taxonomy in biological control. Insect sciences Applications, 8, 841-844.

Moure, J.S. \& Sakagami, S.F. (1962). As Mamangabas Sociais do Brasil (Bombus Latreille) (Hymenoptera, Apoidea). Studia Entomologica. 5, 65-194.

Müller, A. (2006). A scientific note on Bombus inexspectatus (Tkalcu, 1963): evidence for a social parasitic mode of life. Apidologie, 37, 408-409.

Müller, O.F. (1776). Zoologia Danica prodromus, seu animalium Dania et Norvegiae indigenarum characteres, nomina, et synonyma imprimis popularium. Hallager (Ed). Haniae (Köbenhavn).

Murray, T.E., Fitzpatrick, U., Brown, M.J.F. \& Paxton, R.J. (2008). Cryptic species diversity in a widespread bumble bee complex revealed using mitochondrial DNA RFLPs. Conservation Genetics, 9, 653-666.

Ndiaye, A., Hima, K., Dobigny, G., Sow, A., Dalecky, A., Bâ, K., Thiam, M. and Granjon, L. (2014). Integrative taxonomy of a poorly known Sahelian rodent, Gerbillus nancillus (Muridae, Gerbillinae). Zoologischer Anzeiger, 253, 430-439.

Nieto, A., Roberts, S.P.M., Kemp, J., Rasmont, P., Kuhlmann, M., García Criado, M., Biesmeijer, J.C., Bogusch, P., Dathe, H.H., De la Rúa, P., De Meulemeester, T., Dehon, M., Dewulf, A., Ortiz-Sánchez, F.J., Lhomme, P., Pauly, A., Potts, S.G., Praz, C., Quaranta, M., Radchenko, V.G., Scheuchl, E., Smit, J., Straka, J., Terzo, M., Tomozii, B., Window, J. \& Michez, D. (2014). European Red List of bees. Luxembourg: Publication Office of the European Union. 
Oksanen, F.J., Blanchet, G., Kindt, R., Legendre, P., Minchin, P.R., O'Hara, R.B., Simpson, G.L., Solymos, P., Stevens, M.H.H. \& Wagner, H. (2011). Vegan: Community Ecology Package. Tertiary Vegan: Community Ecology Package.

Oleksa, A. \& Tofilski, A. (2015). Wing geometric morphometrics and microsatellite analysis provide similar discrimination of honey bee subspecies. Apidologie, 46, 49-60.

Padial, J.M., Miralles, A., De la Riva, I. \& Vences, M. (2010). The integrative future of taxonomy. Frontiers in zoology, 7, 16.

Paquin, P., Dupérré, N., Cokendolpher, J.C., White, K. \& Hedin, M. (2008). The fundamental importance of taxonomy in conservation biology: the case of the eyeless Cicurina bandida (Araneae: Dictynidae) of central Texas, including new synonyms and the description of the male of the species. Invertebrate Systematics, 22, 139-149.

Paterson, H.E.H. (1985). The Recognition Concept of Species. Transvaal Museum Monograph, 4, 21-29.

Pérez, J. (1879). Contribution à la faune des apiaires de France. 1re partie. Actes de la Société linnéenne de Bordeaux, 33, 119-229.

Phillimore, A.B. \& Owens, I.P.F. (2006). Are subspecies useful in evolutionary and conservation biology? Proceedings of the Royal Society B: Biological Sciences, 273, 1049-1053.

Posada, D. (2008). jModelTest: Phylogenetic model averaging. Molecular Biology and Evolution, 25, 1253-1256.

R Development Core Team (2016). R: A language and environment for statistical computing.

Radoszkowski, O. (1877). 3 Maya. 1) Bombus daghestanicus 2) Bombus mlokosievitzii. Trudy russkogo entomologicheskogo Obshchestva, 13, VII-VIII.

Radoszkowski, O. (1888). Etudes hyménoptérologiques. I. Revisions des armures copulatrices des mâles. II: Description de nouvelles espèces russes. Trudy russkogo 
entomologicheskogo Obshchestva, 22, 315-337.

670

671

672

673

674

675

676

677

678

679

680

681

682

683

684

685

686

687

688

689

690

691

692

693

Rasmont, P. (1983). Catalogue commenté des Bourdons de la région ouest-paléarctique (Hymenoptera, Apoïdea, Apidae). Notes fauniques de Gembloux, 7, 1-72.

Rasmont, P., Coppée, A., Michez, D. \& De Meulemeester, T. (2008). An overview of the Bombus terrestris (L. 1758) subspecies (Hymenoptera: Apidae). Annales de la Société Entomologique de France, 44, 243-250.

Rasmont, P. \& Iserbyt, S. (2014). Atlas of the European Bees: genus Bombus. 3d Edition. STEP Project. Status and Trends of European Pollinators, Atlas Hymenoptera, Mons, Gembloux (Belgium), 1.

Rasmont, P., Franzen, M., Lecocq, T., Harpke, A., Roberts, S., Biesmeijer, K., Castro, L., Cederberg, B., Dvorak, L., Fitzpatrick, U., Gonseth, Y., Haubruge, E., Mahe, G., Manino, A., Michez, D., Neumayer, J., Odegaard, F., Paukkunen, J., Pawlikowski, T., Potts, S., Reemer, M., Settele, J., Straka, J. \& Schweiger, O. (2015a). Climatic Risk and Distribution Atlas of European Bumblebees. BioRisk, 10, 1-236.

Rasmont, P., Roberts, S., Cederberg, B., Radchenko, V. \& Michez, D. (2015b). Bombus inexspectatus. The IUCN Red List of Threatened Species 2015: e.T13340462A57349805.http://dx.doi.org/10.2305/IUCN.UK.20151.RLTS.T13340462A 57349805.en. The IUCN Red List of Threatened Species 2015: e.T13340462A57349805. http://dx.doi.org/10.2305/IUCN.UK.2015-1.RLTS.T13340462A57349805.en.

Reid, N.M. \& Carstens, B.C. (2012). Phylogenetic estimation error can decrease the accuracy of species delimitation: A Bayesian implementation of the general mixed Yulecoalescent model. BMC Evolutionary Biology, 12.

Rezac, M., Gasparo, F., Kral, J. \& Heneberg, P. (2014). Integrative taxonomy and evolutionary history of a newly revealed spider Dysdera ninnii complex (Areneae: Dysderidae). Zoological Journal of the Linnean Society, 172(2), 451-474. 
Ronquist, F. \& Huelsenbeck, J.P. (2003). MrBayes 3: Bayesian phylogenetic inference under mixed models. Bioinformatics, 19, 1572-1574.

Sackett, L.C., Seglund, A., Guralnick, R.P., Mazzella, M.N., Wagner, D.M. \& Martin, A.P. (2014). Evidence for two subspecies of Gunnison's prairie dogs (Cynomys gunnisoni), and the general importance of the subspecies concept. Biological Conservation, 174, 111.

Schlick-Steiner, B.C., Steiner, F.M., Seifert, B., Stauffer, C., Christian, E. \& Crozier, R.H. (2010). Integrative taxonomy: a multisource approach to exploring biodiversity. Annual Review of Entomology, 55, 421-438.

Skorikov, A.S. (1908). Novyya formy shmeley (Hymenoptera, Bombidae). (Predvaritel'nye diagnozy). I. Russkoe entomologicheskoe Obozrenie, 7, 111-113.

Skorikov, A.S. (1914). Les formes nouvelles des bourdons (Hymenoptera, Bombidae). V. Russkoe entomologicheskoe Obozrenie, 14, 119-129.

Skorikov, A.S. (1922). Palaearctic bumble bees. Part I. General biology (including zoogeography) (in russian). Izvestiya Severnoi oblastnoi stantsii zashchity rastenii ot vreditelei, 4, 1-160.

Suzuki, R. \& Shimodaira, H. (2011). Pvclust: Hierarchical Clustering with P-Values via Multiscale Bootstrap Resampling.

Terzo, M., Urbanová, K., Valterová, I. \& Rasmont, P. (2005). Intra and interspecific variability of the cephalic labial glands' secretions in male bumblebees: the case of Bombus (Thoracobombus) ruderarius and B. (Thoracobombus) sylvarum Hymenoptera, Apidae. Apidologie, 36, 85-96.

Tkalců, B. (1963). Eine neue Hummel-Art der Gattung Agrobombus Vogt aus dem Alpengebiet. Cas. Cesk. Spol. Entomo., 60, 183-196.

Tkalců, B. (1965). Über Agrobombus inexspectatus Tkalců. Reichenbachia, 5, 225-230. 
Tkalců, B. (1974). Beitrag zur Kenntnis der Hummelfauna der französischen Basses-Alpes (Hymenoptera, Apoidea, Bombinae). Acta Rerum naturalium Musei nationalis Slovenici Bratislava, 20, 167-186.

Tòth, M., Löfstedt, C., Blair, B.W., Cabello, T., Farag, A.I., Hansson, B.S., Kovalev, B.G., Maini, S., Nesterov, E.A., Pajor, I., Sazonov, A.P., Shamshev, I.V., Subchev, M. \& Szöcs, G. (1992). Attraction of male turnip moths Agrotis segetum (Lepidoptera: Noctuidae) to sex pheromone components and their mixtures at 11 sites in Europe, Asia, and Africa. Journal of Chemical Ecology, 18, 1337-1347.

Vereecken, N.J., Mant, J. \& Schiestl, F.P. (2007). Population differentiation in female sex pheromone and male preferences in a solitary bee. Behavioral Ecology and Sociobiology, $61,811-821$.

Vogt, O. (1909). Studien über das Artproblem. 1. Mitteilung. über das Variieren der Hummeln. I. Teil. Schriften der berlinischen Gesellschaft Naturforschender, Freunde, Berlin, 1909, 28-84.

Wheeler, Q.D., Raven, P.H. \& Wilson, E.O. (2004). Taxonomy: Impediment or expedient? Science, 303, 285.

White, B.P., Pilgrim, E.M., Boykin, L.M., Stein, E.D. \& Mazor, R.D. (2014). Comparison of four species-delimitation methods applied to a DNA barcode data set of insect larvae for use in routine bioassessment. Freshwater Science, 33, 338-348.

Wilcox, T.P., Zwickl, D.J., Heath, T.A. \& Hillis, D.M. (2002). Phylogenetic relationships of the dwarf boas and a comparison of Bayesian and bootstrap measures of phylogenetic support. Molecular Phylogenetics and Evolution, 25, 361-371.

Williams, P.H. (1998). An annoted checklist of bumble bees with an analysis of patterns of description (Hymenoptera: Apidae, Bombini). Bulletin of the Natural History Museum (Entomology), 67, 79-152. 
Williams, P.H., Brown, M.J.F., Carolan, J.C., An, J., Goulson, D., Aytekin, A.M., Best, L.R., Byvaltsev, A.M., Cederberg, B., Dawson, R., Huang, J., Ito, M., Monfared, A., Raina, R.H., Schmid-Hempel, P., Sheffield, C.S., Šima, P. \& Xie, Z. (2012). Unveiling cryptic species of the bumblebee subgenus Bombus s. str. worldwide with COI barcodes (Hymenoptera: Apidae). Systematics and Biodiversity, 10, 21-56.

Yarrow, I.H.H. (1970). Is Bombus inexspectatus (Tkalcu) a workless parasite? Insectes Sociaux, 17, 95-112.

Žáček, P., Prchalová-Hornákov, D., Tykva, R., Kindl, J., Vogel, H., Svatoš, A., Pichová, I. \& Valterová, I. (2013). De Novo Biosynthesis of Sexual Pheromone in the Labial Gland of Bumblebee Males. ChemBioChem, 14, 361-371.

Zwickl, D.J. (2006). Genetic algorithm approaches for the phylogenetic analysis of large biological sequence datasets under the maximum likelihood criteria. The University of Texas at Austin Editor.

\section{Figures}



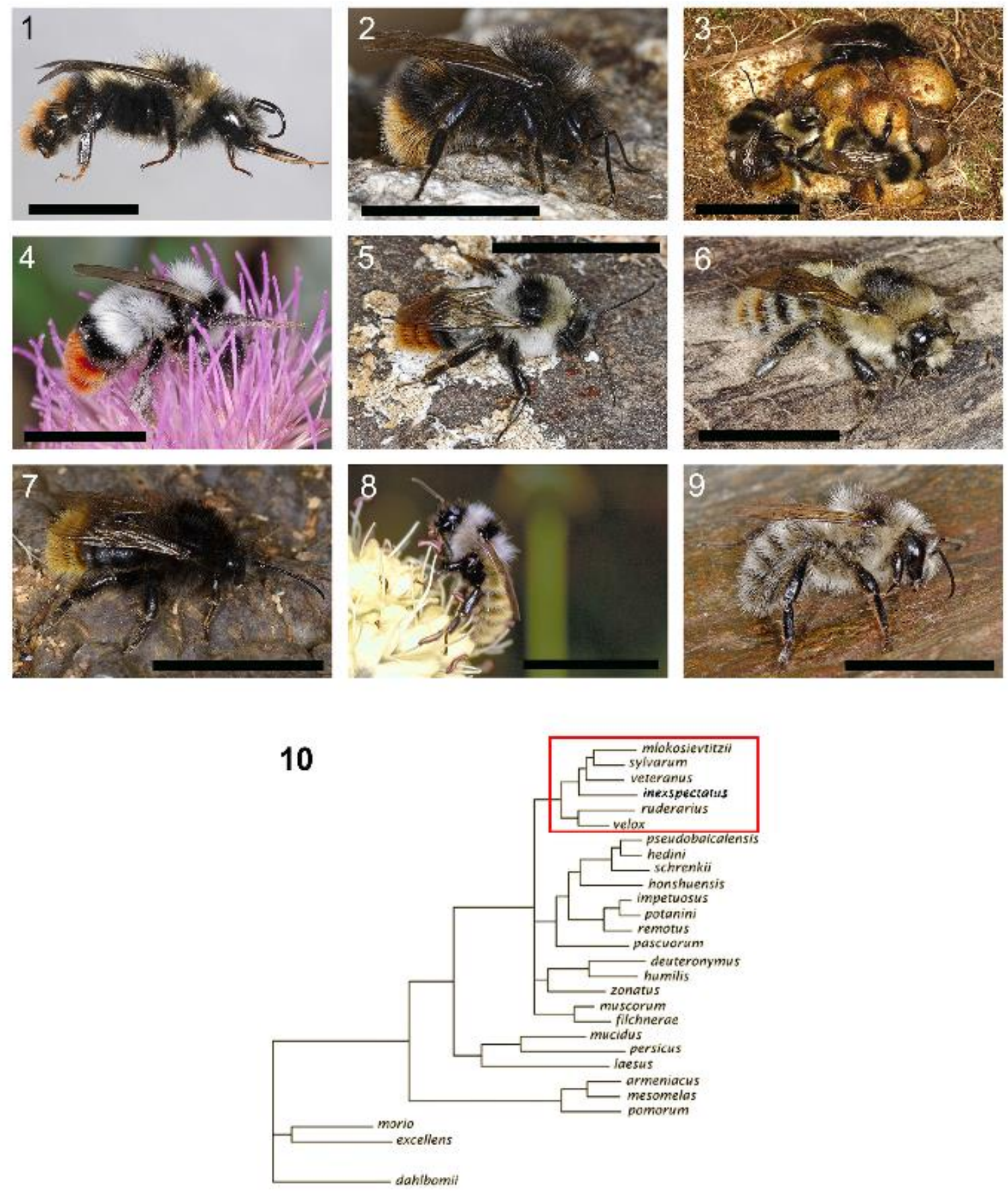

762 Figure 1. Photos of some studied bumblebee species: A) Bombus inexspectatus male from

763 Alps, Italy; B) B. mlokosievitzii vogtiellus male from Turkey ; C) B. ruderarius ruderarius

764 and B. ruderarius montanus from Pyrenees, France; D) B. ruderarius simulatilis female from

765 Turkey; E) B. sylvarum daghestanicus male from Turkey; F) B. sylvarum sylvarum female

766 from Pyrenees, France; G) B. sylvarum nigrescens male from Sweden; H) B. velox male from

767 Turkey and I) B. veteranus from the Netherlands. All black lines correspond to a scale of 1 

red box shows the monophyletic group of all species included in this study (according to 770 Hines \& Cameron 2010).

771 
- modoranis iFrancej nuderarus iswitzerlani

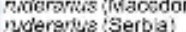
nutwraries islavikia cudoranus isweden? sertus i Kyry yze:en sartus (wiongolia)

montanus (Andorra)

simulenus itukey?

simaigtiis flism?

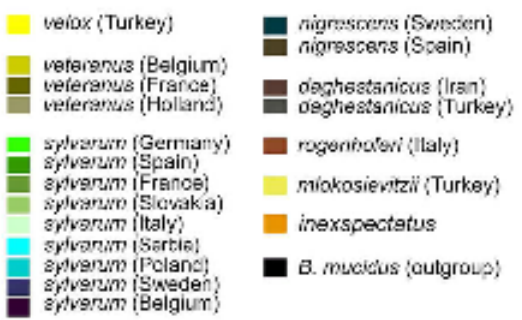

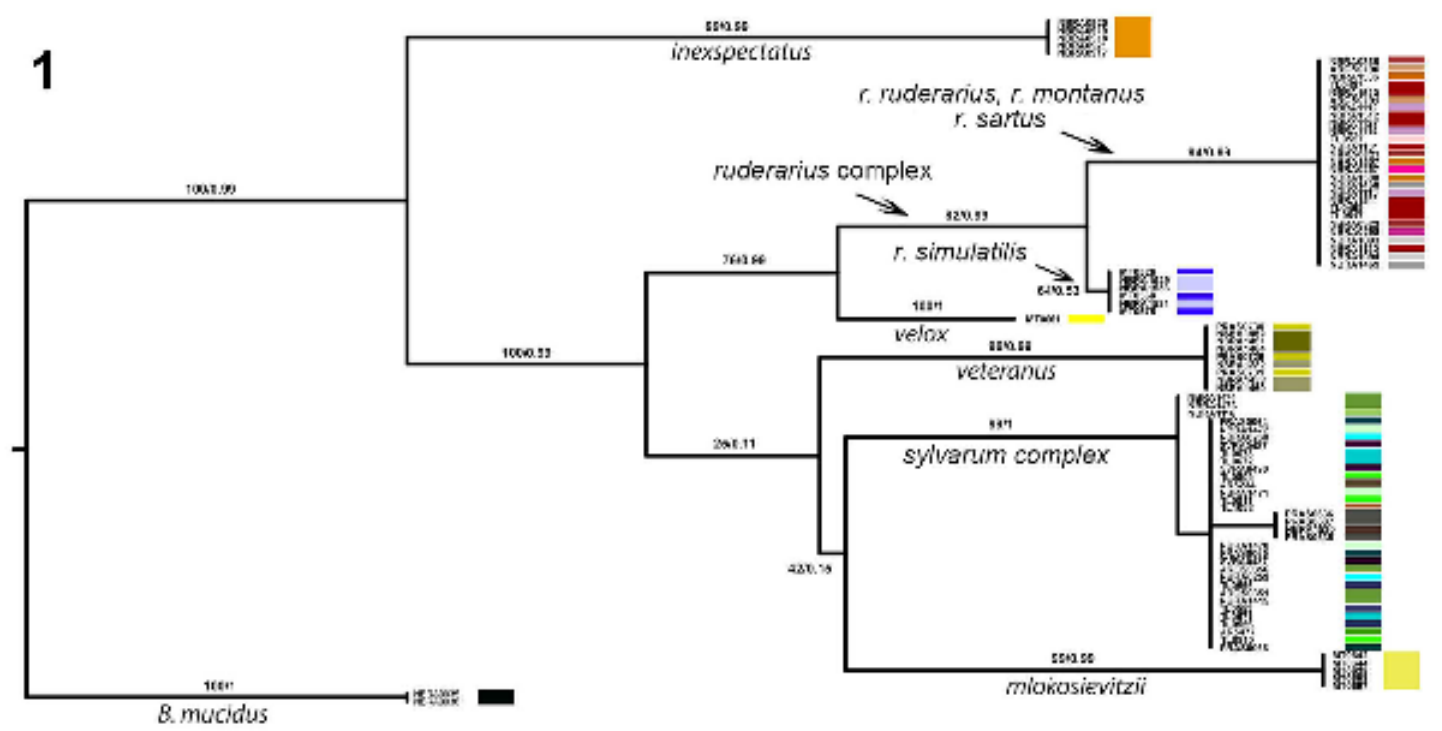

0.007

\section{2}

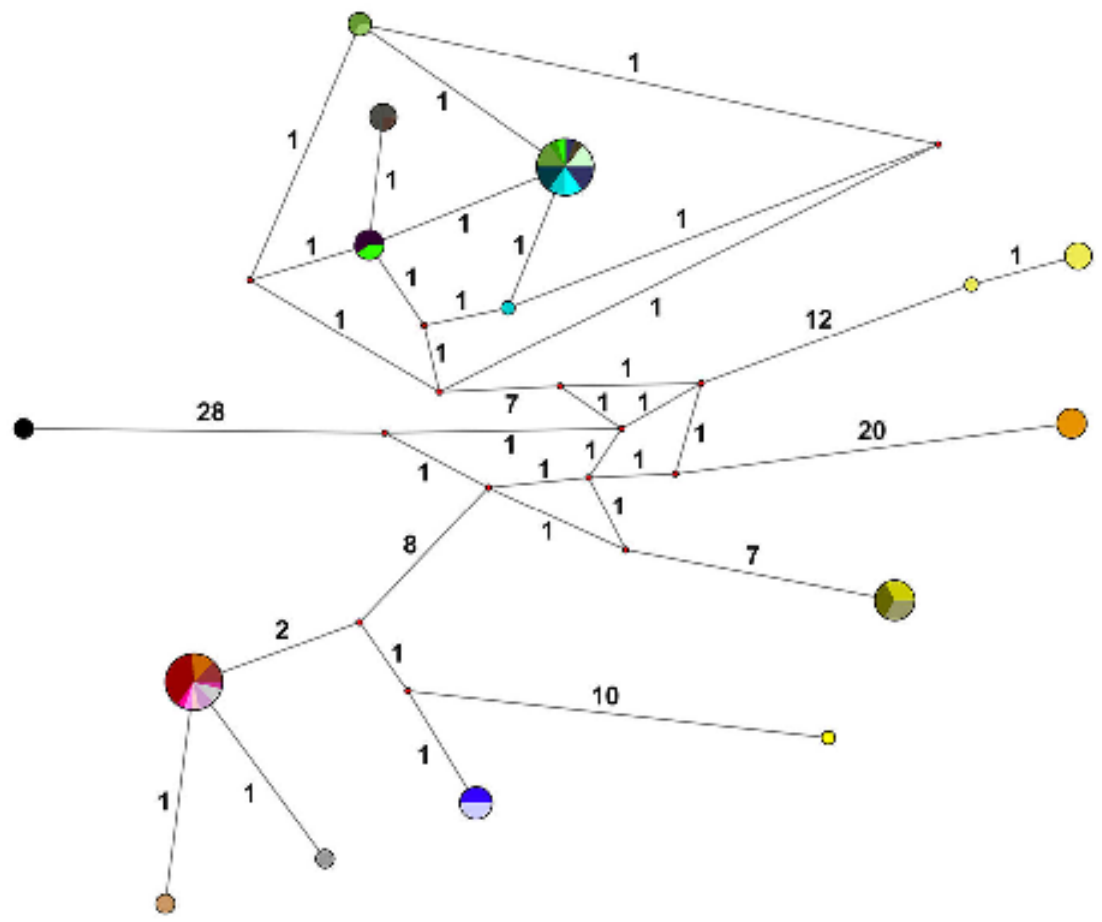

773 Figure 2. A: Majority rule (50\%) consensus tree based on maximum likelihood analyses of 
775 probabilities. B: Median-joining network of haplotypes based on cytochrome oxidase 1 (COI)

776 sequences. Numbers on the lines correspond to the number of mutation between haplotypes.

777 


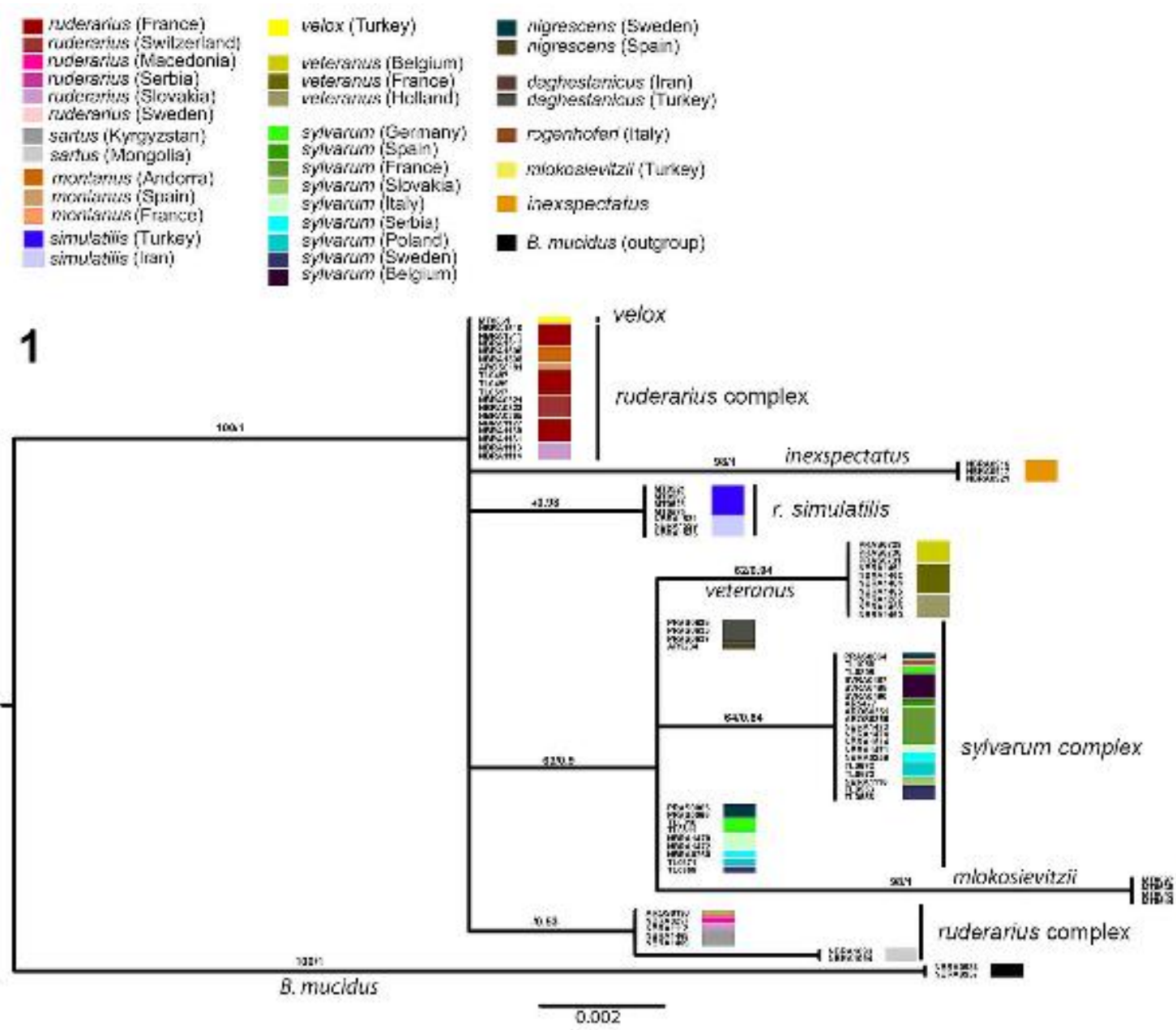

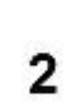

2

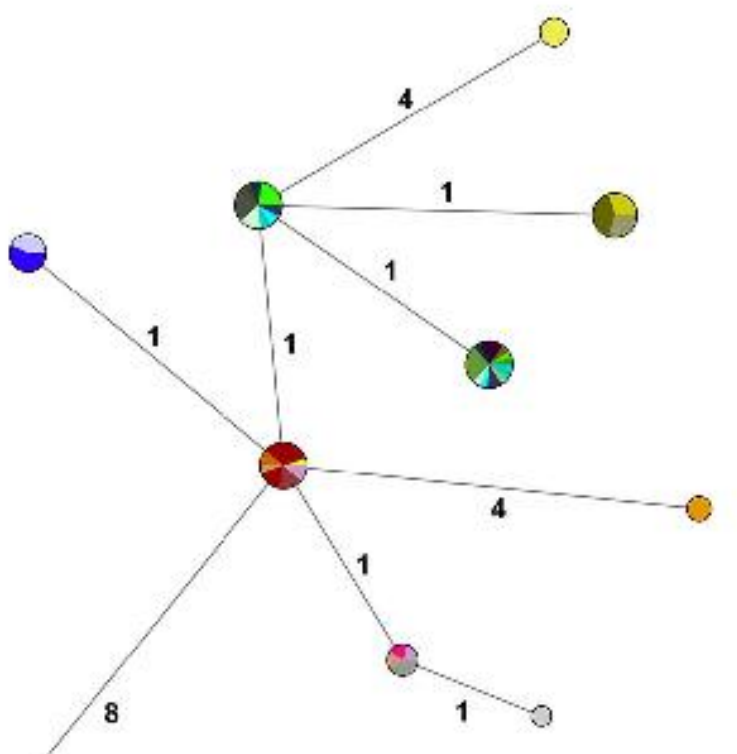

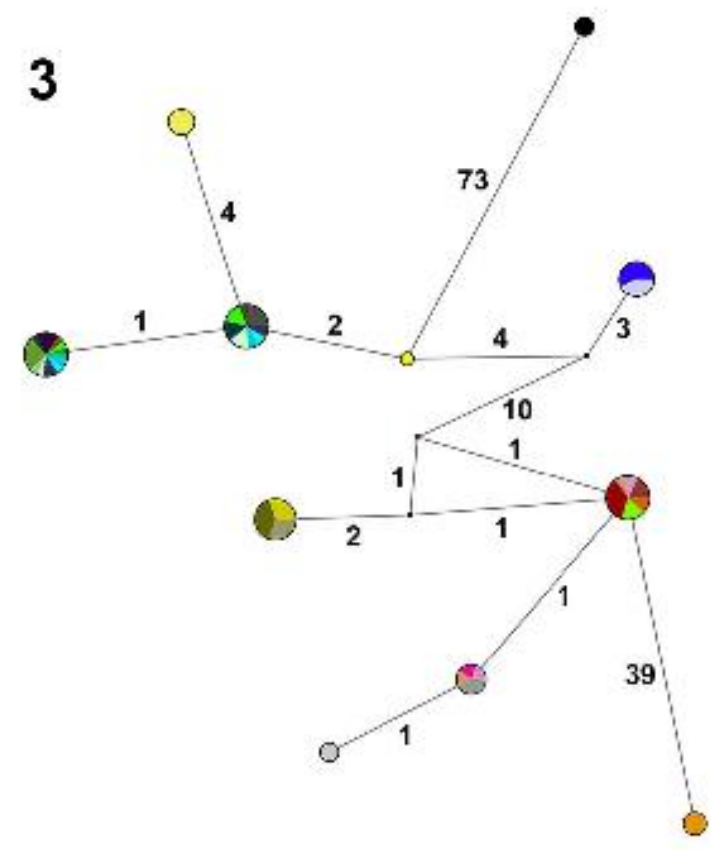

Figure 3. A: Majority rule (50\%) consensus tree based on maximum likelihood analyses of PEPCK. Values above tree branches are maximum likelihood bootstrap values/Bayesian 
781 posterior probabilities. B: Median-joining network of haplotypes based on 782 phosphoenolpyruvate carboxykinase (PEPCK) sequences. This network do not consider the 783 Gap sites. C: Median-joining network of haplotypes based on phosphoenolpyruvate 784 carboxykinase (PEPCK) sequences. This network consider the Gap sites. Numbers on the 785 lines correspond to the number of mutation between haplotypes. 


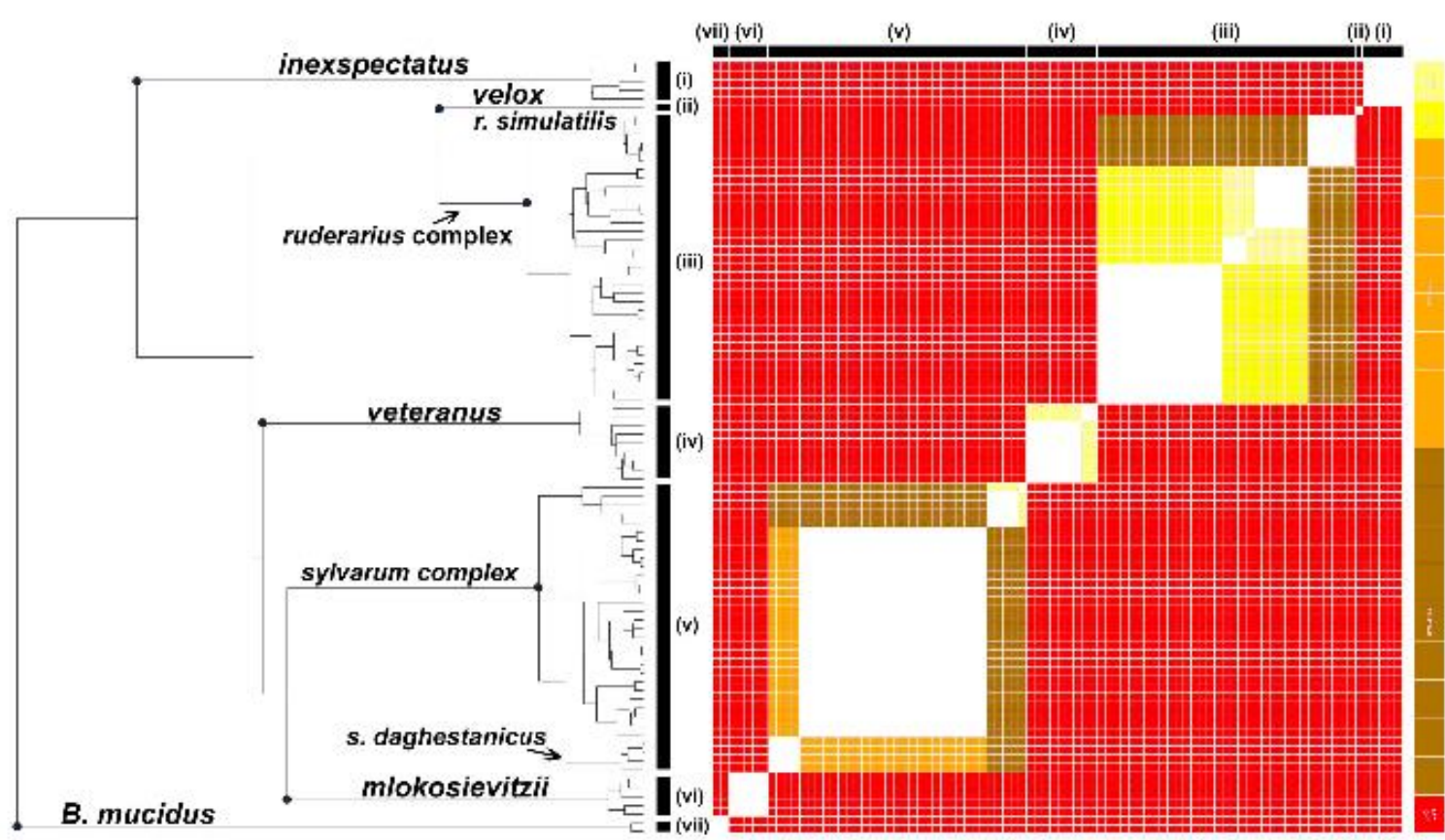

788 Figure 4. bGMYC results based on COI phylogenetic tree. The vertical and horizontal lines

789 correspond to the eight different groups shown on the tree. The scale corresponds to the 790 probability to be conspecific.

791

792 


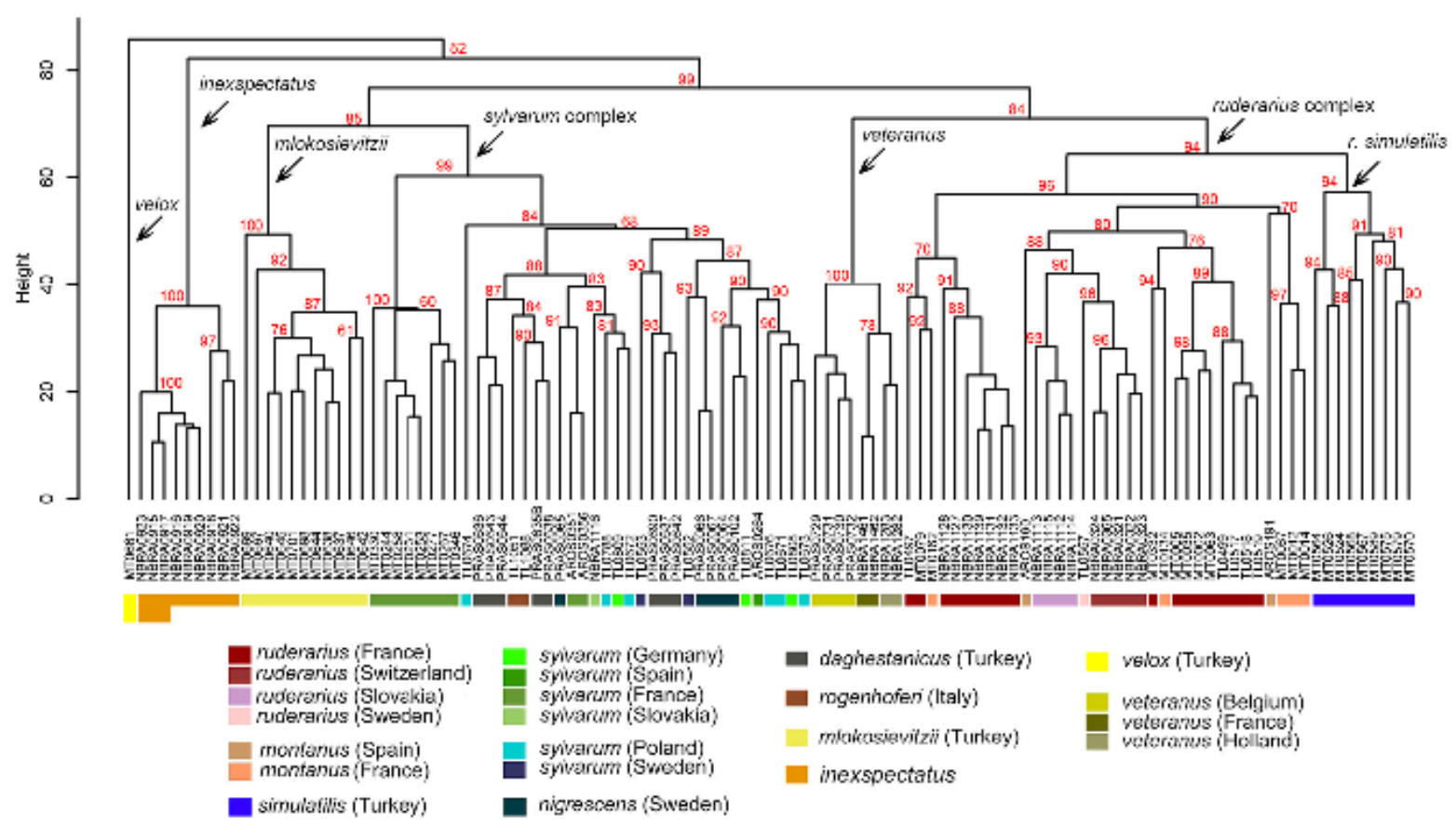

794 Figure 5. Unweighted pair group method with arithmetic mean (UPGMA) cluster based on a

795 Canberra distance matrix calculated from the cephalic labial gland secretions matrix of velox,

796 veteranus, inexspectatus, ruderarius, montanus, simulatilis, mlokosievitzii, sylvarum,

797 daghestanicus, nigrescens and rogenhoferi. The values near the node are multiscale bootstrap resampling. 